\title{
Improvement of Biotechnological Xylitol Production by Glucose During Cultive of Candida guilliermondii in Sugarcane Bagasse Hydrolysate
}

\author{
Débora Danielle Virgínio da Silva ${ }^{1}$, Ismael Maciel de Mancilha ${ }^{1,2}$, Silvio Silvério da Silva ${ }^{1}$ \\ and Maria das Graças de Almeida Felipe ${ }^{1 *}$ \\ ${ }^{1}$ Departamento de Biotecnologia; Faculdade de Engenharia Química de Lorena; C. P. 116; 12.600-970; Lorena- \\ SP - Brasil. ${ }^{2}$ Departamento de Tecnologia de Alimentos; Universidade Federal de Viçosa; \\ mgafelipe@debiq.faenquil.br; 36.570-000; Viçosa-MG - Brasil
}

\begin{abstract}
The effect of glucose on xylose-to-xylitol bioconversion by Candida guilliermondii was examined by adding it to sugarcane bagasse hydrolysate medium to obtain different glucose:xylose ratios (1:25, 1:12, 1:5 and 1:2.5). Under experimental conditions, increasing glucose:xylose ratio improved the assimilation of the xylose present in the hydrolysate by yeast, resulting in biomass increase, and in the formation of xylitol and glycerol/ethanol by-products. Maximum values of xylitol yield $\left(0.59 \mathrm{~g} \mathrm{~g}^{-1}\right)$ and volumetric productivity $\left(0.53 \mathrm{~g} \mathrm{l}^{-1} . h^{-1}\right)$ were obtained with glucose:xylose ratio of 1:5, resulting in the higher conversion efficiency (64.3\%).
\end{abstract}

Key words: Candida guilliermondii, glucose, sugarcane bagasse hydrolysate, xylitol, xylose

\section{INTRODUCTION}

Xylose metabolism by Candida guilliermondii starts with the reduction of xylose to xylitol catalysed by NADPH-dependent xylose reductase (XR). Xylitol is oxidized to xylulose by $\operatorname{NAD}\left(\mathrm{P}^{+}\right)$dependent xylitol dehydrogenase (XDH) and xylulose is then, phosphorylated to xylulose-5phosphate, which can be converted in pyruvate through a connection between pentose phosphate (PPP) and glycolytic pathways (Hahn-Hägerdal et al. 1994; Silva et al. 1996). The general pattern observed for yeast batch cultivation on sugar mixtures is the inhibition or retardation of xylose utilization by the presence of glucose in the growth media. The presence of this readily metabolize hexose can induce regulatory problems due to an interaction between the different sugars metabolisms resulting in poor xylose assimilation, and hence greatly influence xylitol yield and productivity (Tavares et al. 2000). According to Walker (1998), the presence of glucose in hemicellulosic hydrolysate can inhibit xylose metabolism by repression or inactivation of catabolic enzymes and transport system of this pentose.

Previous studies have shown that the presence of glucose can improve xylitol production during fermentations in synthetic medium. Rosa et al. (1998) observed an improvement of xylitol formation by $C$. guilliermondii in synthetic medium containing xylose $\left(60 \mathrm{~g} \mathrm{l}^{-1}\right)$ and glucose (5 $\mathrm{g} \mathrm{l}^{-1}$ ) and according to Felipe et al. (1993), this improvement depended on glucose:xylose ratio.

\footnotetext{
${ }^{*}$ Author for correspondence
} 
Sugai and Delgenes (1995) reported that the glucose partially repressed the induction of aldose reductase of $C$. guilliermondii by xylose, and the intensity of the catabolite repression was correlated to the glucose concentration in the induction system.

The stimulation of xylose metabolism by glucose can be explained by the generation of intermediary metabolites for the initial steps of xylose metabolism and the pentose phosphate pathway through glucose metabolism, since coenzymes such as NADH and NADPH are essential for the enzymatic reduction of xylose with xylose reductase (Meinander et al. 1999; Chung et al.
2002). Different agro-industrial and forest residues, such as sugarcane bagasse, wheat straw, rice straw, oat hulls and eucalyptus wood have been employed for biotechnological xylitol obtention. An acid hydrolysis process is used to separate hemicellulosic fraction. The concentration of main sugars in the hydrolysate differ depending on the raw material utilized (Tab. 1); besides, the sugar concentration and the proportion among these sugars in the hydrolysates influence this process. Sugarcane bagasse hydrolysate is the most used hydrolysate for biotechnological xylitol production (Alves et al. 1998; Sene et al. 2001; Rodrigues et al. 2003a; Silva et al. 2004).

Table 1 Main sugars found in different hemicellulosic hydrolysates

\begin{tabular}{ccccc}
\hline Hemicellulosic Hydrolysate & \multicolumn{3}{c}{ Sugars $\left(\mathbf{g ~}^{\mathbf{1}}\right)$} & \multirow{2}{*}{ Reference } \\
\cline { 1 - 4 } & Xylose & Glucose & Arabinose & \\
Sugarcane bagasse & 18.24 & 1.20 & 1.71 & Rodrigues et al. 2003b \\
Wheat straw & 10.65 & 2.79 & 1.78 & Canilha et al. 2003 \\
Rice straw & 18.33 & 3.29 & 3.40 & Mussato and Roberto 2003 \\
Oat hull & 32.33 & 1.61 & 3.03 & Felipe et al. 2003 \\
Eucalyptus wood & 19.17 & 2.54 & 0.41 & Canettieri et al. 2002 \\
\hline
\end{tabular}

Xylitol, commercially produced by chemical processes (Melaja and Hämäläinen 1977), has attractive characteristics for food, pharmaceutical or odontological industries. Two of the most significant characteristics are its high sweetening and anti-cariogenic power (Makinen et al. 2001). Thus, its metabolism is independent of insulin and it contributes less than other sugars to the formation of fat tissues, so xylitol is recommended to diabetic and obese people (Aguiar et al. 1999; Makinen 2000). Besides these properties, recent researches have shown that xylitol prevents otitis (Uhari et al. 2000), osteoporosis (Matilla et al. 2002) and respiratory infections (Zabner et al. 2000). According to FDA (Food and Drug Administration, USA), xylitol is classified as "GRAS" (Generally Recognized as Safe), and can be utilized alone or together with other sweeteners (Aguiar et al. 1999).

There are many studies about biotechnological xylitol production from sugarcane bagasse hydrolysate and several parameters of this bioprocess have been established. However, studies for better understanding of the metabolic pathways involved on xylose to xylitol bioconversion are necessary, mainly about the influence of glucose in this metabolism. Thus, this work was done to evaluate the effects of the different glucose: xylose ratios (1:25 1:12, 1:5, $1: 2.5)$ on xylose-xylitol bioconversion during the cultivation of Candida guilliermondii FTI 20037 in sugarcane bagasse hemicellulosic hydrolysate.

\section{MATERIAL AND METHODS}

\section{Microorganism and inoculum preparation}

The experiments were carried out with $C$. guilliermondii FTI 20037 maintained at $4{ }^{\circ} \mathrm{C}$ on malt-extract agar slants. The medium used for inoculum preparation contained xylose $\left(30.0 \mathrm{~g} \mathrm{l}^{-1}\right)$, rice bran extract $\left(20.0 \mathrm{~g} \mathrm{l}^{-1}\right),\left(\mathrm{NH}_{4}\right)_{2} \mathrm{SO}_{4}\left(2.0 \mathrm{~g} \mathrm{l}^{-1}\right)$ and $\mathrm{CaCl}_{2} \cdot 2 \mathrm{H}_{2} \mathrm{O}\left(0.1 \mathrm{~g} \mathrm{l}^{-1}\right)$. Erlenmeyer flasks (125 $\mathrm{ml}$ ), each containing $50 \mathrm{ml}$ of medium, were inoculated and incubated in a rotary shaker (200 rpm) at $30{ }^{\circ} \mathrm{C}$ for $24 \mathrm{~h}$. Afterwards, the cells were separated by centrifugation $(2000 \mathrm{x} \mathrm{g} ; 20 \mathrm{~min})$, rinsed twice with distilled water, and the cell pellet was ressuspended in an adequate volume of distilled water. The initial cell concentration for all the experiments was $1.0 \mathrm{~g} \mathrm{l}^{-1}$. 


\section{Preparation of the bagasse hydrolysate}

Sugarcane bagasse was hydrolysed in a 3501 steel reactor at $121{ }^{\circ} \mathrm{C}$ for $20 \mathrm{~min}$ with $\mathrm{H}_{2} \mathrm{SO}_{4}$ at $1: 10$ solid/liquid ratio (100 mg of $\mathrm{H}_{2} \mathrm{SO}_{4}$ per gram of dry matter). The hydrolysate was first filtered and concentrated at $70{ }^{\circ} \mathrm{C}$ under vacuum to obtain a threefold increase in the xylose content. Next, it was submitted to a treatment consisting in $\mathrm{pH}$ adjustment to 7.0 with $\mathrm{CaO}$ (commercial grade) and to 2.5 with $\mathrm{H}_{3} \mathrm{PO}_{4}$, followed by the addition of $1.0 \% \mathrm{w} / \mathrm{v}$ activated charcoal (refined powder), for $30 \mathrm{~min}$, under agitation $\left(200 \mathrm{rpm}, 60{ }^{\circ} \mathrm{C}\right)$. The precipitate formed as a result of this treatment was removed by vacuum filtration, and then the hydrolysate was autoclaved at $111^{\circ} \mathrm{C}$, for $15 \mathrm{~min}$., in order to be used as the fermentation medium.

\section{Medium and fermentation conditions}

The concentrated and treated bagasse hemicellulosic hydrolysate $\quad\left(x y l o s e=46 \quad \mathrm{~g} \mathrm{l}^{-1}\right.$, glucose $=1.8 \mathrm{~g} \mathrm{l}^{-1}$, arabinose $=2.5 \mathrm{~g} \mathrm{l}^{-1}$, acetic acid= $2.4 \mathrm{~g} \mathrm{l}^{-1}$, total phenols $=1.78 \mathrm{~g} \mathrm{l}^{-1}$, furfural $=0.011 \mathrm{~g}$ $\mathrm{l}^{-1}$ and hydroxymethylfurfural $=0.004 \mathrm{~g} \mathrm{l}^{-1}$ ) was supplemented with rice bran extract $\left(20.0 \mathrm{~g} \mathrm{l}^{-1}\right)$, $\left(\mathrm{NH}_{4}\right)_{2} \mathrm{SO}_{4}\left(2.0 \mathrm{~g} \mathrm{l}^{-1}\right)$ and $\mathrm{CaCl}_{2} \cdot 2 \mathrm{H}_{2} \mathrm{O}\left(0.1 \mathrm{~g} \mathrm{l}^{-1}\right)$. Experiments were performed in a KLF 2000 bench-scale fermentor (Bioengineering) with 1.61 of medium (initial $\mathrm{pH}=5.5$ ), at $30{ }^{\circ} \mathrm{C}, 500 \mathrm{rpm}$ and $K_{L}$ a of $17 \mathrm{~h}^{-1}$. To evaluate the effect of glucose: xylose ratio on xylose to xylitol bioconversion by $C$. guilliermondii, glucose was added to the hydrolysate to obtain initial glucose concentrations of $4.0 \mathrm{~g} \mathrm{l}^{-1}$ (glucose: xylose $=1: 12$ ), $9.0 \mathrm{~g} \mathrm{l}^{-1}$ (glucose: xylose=1:5) and $18.0 \mathrm{~g} \mathrm{l}^{-1}$ (glucose: $x y l o s e=1: 2.5$ ). A control experiment was also performed with initial glucose concentration of $2.0 \mathrm{~g} \mathrm{l}^{-1}$ (glucose: xylose $=1: 25$ ratio, usually found in hydrolysate).

\section{Analytical methods}

The concentrations of xylose, glucose, arabinose, xylitol, acetic acid, glycerol and ethanol were determined by HPLC (Waters, Milford, MA) with a refraction index detector on a Bio-Rad Aminex HPX-87H at $45{ }^{\circ} \mathrm{C}$, with $0.01 \mathrm{~N} \mathrm{H}_{2} \mathrm{SO}_{4}$ as the eluent at a $0.6 \mathrm{ml} \mathrm{m^{-1 }}$ flow rate. A HewlettPackard RP 18 column at $25{ }^{\circ} \mathrm{C}$ with acetonitrile:water $(1: 8)$ and $1 \%$ acetic acid as the eluent, and a $0.8 \mathrm{ml} \mathrm{min}^{-1}$ flow rate was employed for determination of furfural and hydroxymethylfurfural concentrations in a visible ultraviolet-light detector (SPD-10 ${ }^{\mathrm{A}}$ UV-VIS). Cell growth was monitored by measuring absorbance at $600 \mathrm{~nm}$ (Beckman-DU 640B spectrophotometer). Cell concentration was calculated based on the relation of absorbance and cell dry weight through a calibration curve. The oxygen transfer volumetric coefficient $\left(\mathrm{K}_{\mathrm{L}} \mathrm{a}\right)$ was determined by the gassing-out methodology (Pirt 1975). Xylose, glucose, arabinose and xylitol uptake rates were determined by the analysis of angular coefficients of the straight lines, using the range of higher linearity [0-48].

\section{RESULTS}

The effect of the glucose:xylose ratio on sugars consumption by $C$. guilliermondii during fermentations in sugarcane bagasse hydrolysate is presented in Fig. 1. According to the results, the xylose assimilation was influenced by glucose concentration. These observations were confirmed by the analysis of angular coefficients of the straight lines, using the range of higher linearity [0-48], which correlated the decrease in xylose levels and fermentation time. Increasing the initial glucose concentration in the medium favoured the xylose assimilation, except during the first $6 \mathrm{~h}$ of fermentation, period corresponding to glucose consumption. Also, it was possible to note that the increase in glucose:xylose ratio resulted in decrease in the xylose uptake rate (Fig. 1). For glucose:xylose ratio of $1: 2.5$, xylose assimilation was $10.8 \%$ higher than that observed for the control medium (glucose: xylose ratio=1:25) after $48 \mathrm{~h}$ fermentation.

Glucose, arabinose and acetic acid were totally consumed in all fermentations (Fig. 1). Contrary to the behaviour observed for xylose consumption, glucose:xylose ratio did not have any appreciable effect on arabinose assimilation and it was not possible to correlate the increase in glucose concentration in the fermentation medium and the arabinose consumption by $C$. guilliermondii (Fig. 1D). Arabinose assimilation was slow (around $0.03 \mathrm{~g} \mathrm{l}^{-1} \cdot \mathrm{h}^{-1}$ ) and its rate was $90 \%$ lower than xylose consumption rate. In relation to acetic acid (Fig. 1B), whose consumption rate was around $0,04 \mathrm{~g} \mathrm{l}^{-1} \cdot \mathrm{h}^{-1}$ and was accomplished by raising the medium $\mathrm{pH}$ (data not shown), increasing the initial glucose concentration in the medium diminished the acid assimilation rate, as confirmed by the 
analysis of angular coefficients of the straight lines, using the range of higher linearity [0-48].

The increase in glucose:xylose ratio also resulted in improvement in the cell growth (Fig. 2) and xylitol formation (Fig. 3). Glucose:xylose ratio of $1: 2.5$ resulted in cell growth $18.3 \%$ higher than that observed for the control medium. Besides, higher specific growth rate $\left(\mu_{\mathrm{X}}\right)$ and volumetric cell production rate $(\mathrm{Qx})$ with an increase in initial glucose concentration in hydrolysate were observed, except for glucose:xylose ratio of 1:5, for which the cell growth was around $22 \%$ lower than that observed for the glucose:xylose ratio of 1:25 (Fig. 2B).

The lowest cell growth coincided with the highest xylitol amount (26.9 $\left.\mathrm{g} \mathrm{l}^{-1}\right)$ also found with glucose:xylose ratio of $1: 5$ after $72 \mathrm{~h}$ fermentation (Fig. 3). In this condition, after $48 \mathrm{~h}$, xylitol yield was $15.7 \%$ higher and productivity was $23.3 \%$ higher than those observed for the control medium (Tab. 2). An improvement in the xylitol formation rate was also noted, as confirmed by the analysis of angular coefficients of the straight lines using the range of higher linearity [6-48], when the medium contained glucose:xylose ratio of $1: 5$ and 1:2.5 (Fig. 3). After $72 \mathrm{~h}$, the decrease in xylitol concentration coincided with the total consumption of xylose and partial consumption of arabinose and acetic acid, independently on glucose:xylose ratio in the fermentation medium (Fig. 3).

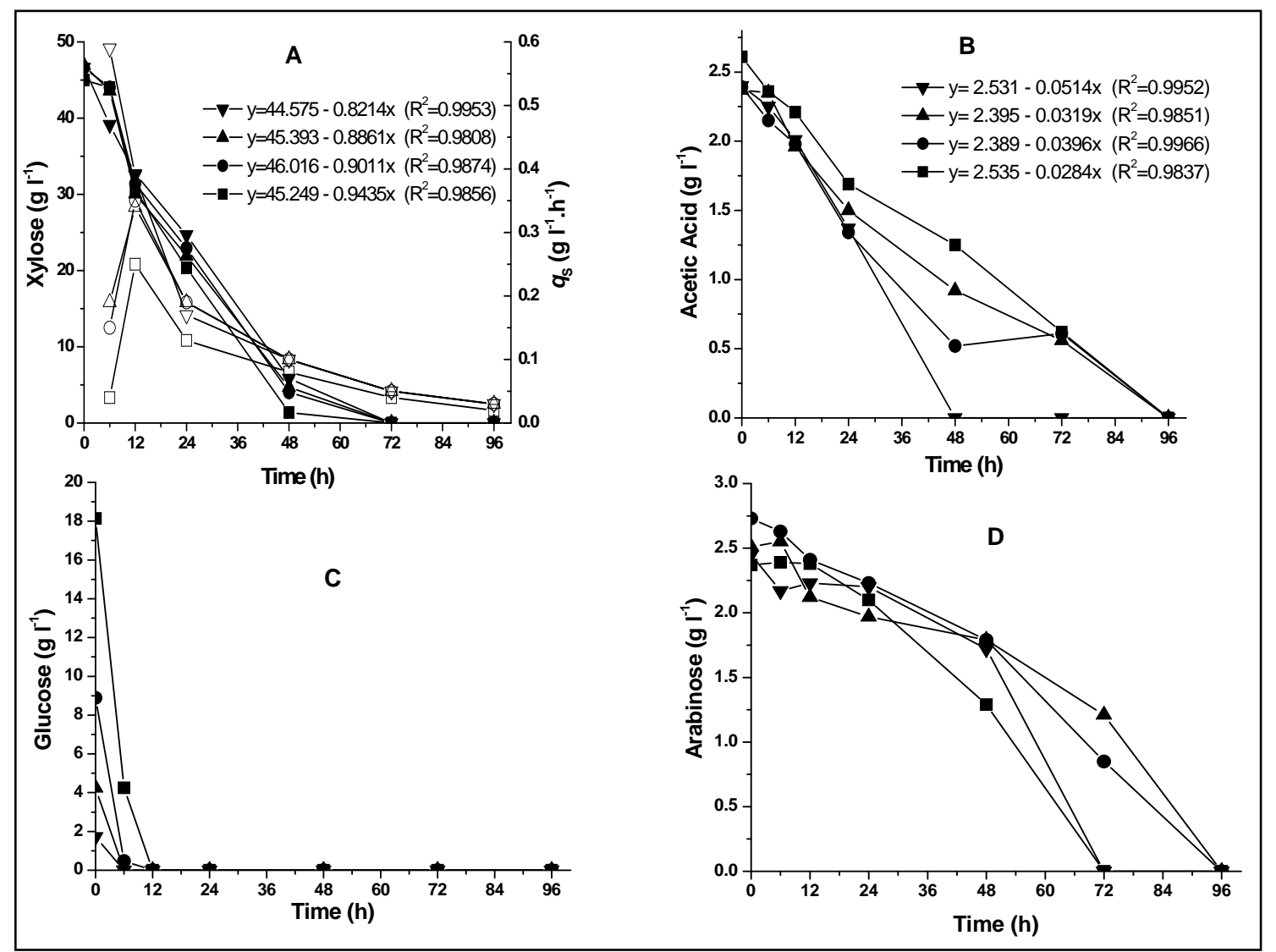

Figure 1 - (A) Xylose consumption (black symbol) and xylose uptake rate - $q_{\mathrm{S}}$ (white symbol), (B) acetic acid, (C) glucose and (D) arabinose concentrations during fermentations of sugarcane bagasse hydrolysate by Candida guilliermondii, with different glucose:xylose ratios: 1:25 (down triangle), 1:12 (up triangle), 1:5 (circle) and 1:2.5 (square). 
Table 2 The effect of glucose:xylose ratio on fermentative parameters after $48 \mathrm{~h}$ fermentation of sugarcane bagasse hydrolysate by Candida guilliermondii

\begin{tabular}{lcccc}
\hline \multicolumn{1}{c}{ Parameters } & \multicolumn{4}{c}{ glucose:xylose ratio } \\
\cline { 2 - 5 } & $\mathbf{1 : 2 5}$ & $\mathbf{1 : 1 2}$ & $\mathbf{1 : 5 . 0}$ & $\mathbf{1 : 2 . 5}$ \\
\hline \multicolumn{1}{c}{ Xylose consumption $(\%)$} & 87.5 & 89.9 & 91.4 & 96.9 \\
$\mathbf{Y}_{\mathbf{P} / \mathbf{S}}\left(\mathrm{g} \mathrm{g}^{-1}\right)$ & 0.51 & 0.45 & 0.59 & 0.55 \\
$\mathbf{Q}_{\text {Pxol }}\left(\mathrm{g} \mathrm{l}^{-1} \cdot \mathrm{h}^{-1}\right)$ & 0.43 & 0.39 & 0.53 & 0.52 \\
$\eta_{\text {xol }}(\%)$ & 55.6 & 49.1 & 64.3 & 60.0 \\
$\mathbf{Y}_{\mathrm{X} / \mathrm{S}}\left(\mathrm{g} \mathrm{g}^{-1}\right)$ & 0.20 & 0,21 & 0.20 & 0.26 \\
$\mathbf{Q}_{\mathbf{X}}\left(\mathrm{g} \mathrm{l}^{-1} \cdot \mathrm{h}^{-1}\right)$ & 0.17 & 0.18 & 0.18 & 0.23 \\
$\mathbf{Q}_{\text {gly }}\left(\mathrm{g} \mathrm{l}^{-1} \cdot \mathrm{h}^{-1}\right)$ & 0.01 & 0.01 & 0.01 & 0.01 \\
$\mathbf{Q}_{\text {eth }}\left(\mathrm{g} \mathrm{l}^{-1} \cdot \mathrm{h}^{-1}\right)$ & 0.04 & 0.10 & 0.11 & 0.12 \\
\hline
\end{tabular}

$\mathbf{Y}_{\mathbf{P} / \mathbf{S}}$ : xylitol yield coefficient (g xylitol/g xylose consumed) $\mathbf{Q}_{\mathbf{P x o l}}$ : xylitol production rate $\eta_{x o l}$ : percentage of xylitol yield from the theorical value

$\mathbf{Y}_{\mathrm{x} / \mathrm{S}}$ : cell yield coefficient ( $\mathrm{g}$ dry cell mass/g xylose consumed)

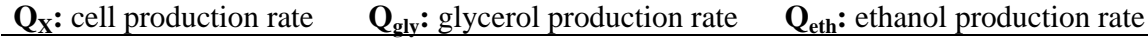

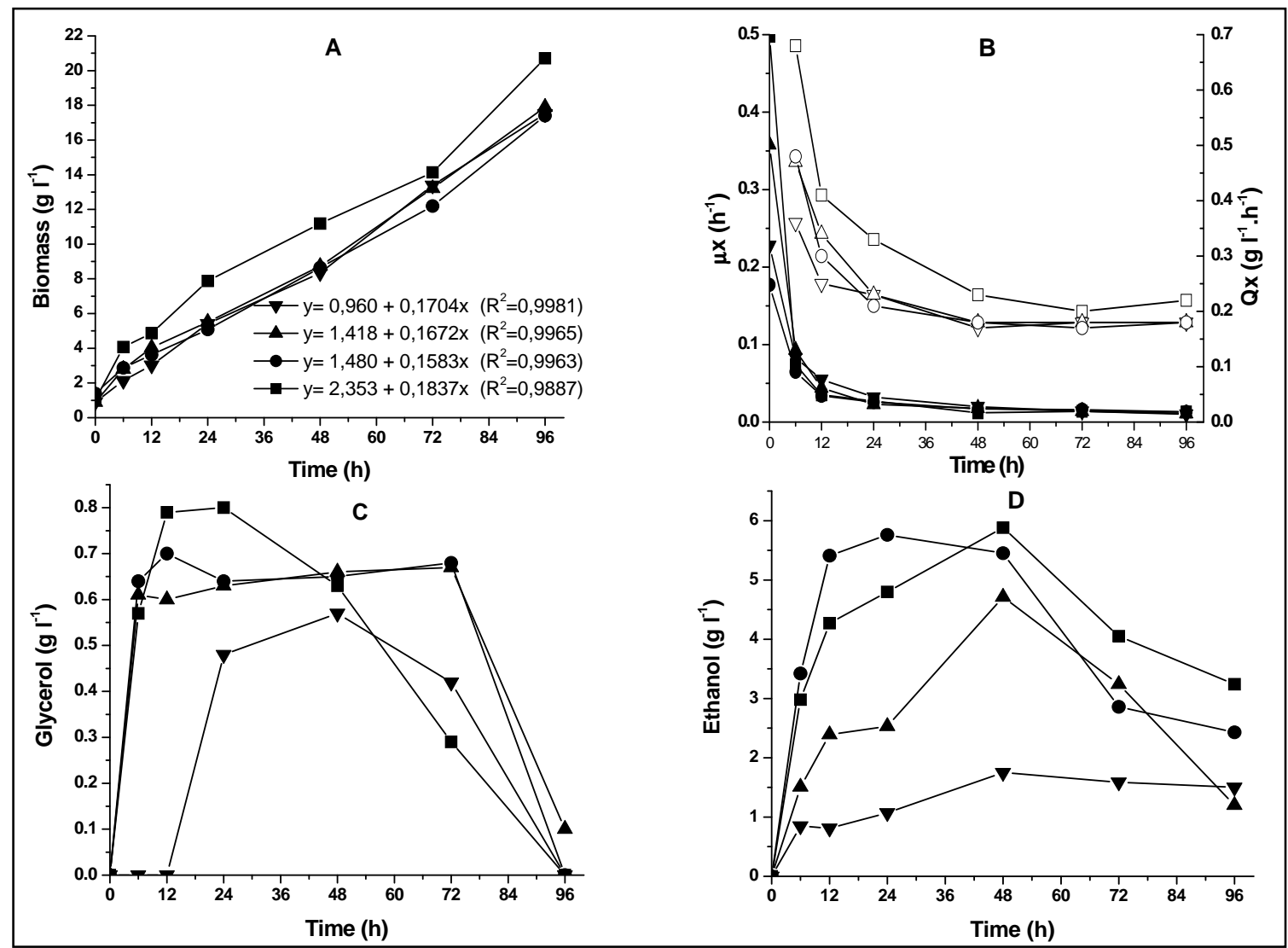

Figure 2 - (A) Biomass formation, (B) specific growth rate, $\mu x$ (black symbol), cell production rate, Qx (white symbol), (C) glycerol, and (D) ethanol concentrations during fermentations of sugarcane bagasse hydrolysate by Candida guilliermondii, with different glucose:xylose ratios: 1:25 (down triangle), 1:12 (up triangle), 1:5 (circle) and 1:2.5 (square). 
Similar to the xylitol formation, the glucose:xylose ratio increase led to the increase of by-products formation; however, the values of glycerol and ethanol productivity were lower than that observed for xylitol (Tab. 2). The highest concentrations of glycerol $\left(0.80 \mathrm{~g} \mathrm{l}^{-1}\right)$ and ethanol $\left(5.88 \mathrm{~g} \mathrm{l}^{-1}\right)$ were found when hydrolysate contained glucose: xylose ratio of 1:2.5 (Fig. 3), corresponding to increases of 1.7 and 3.4 fold when compared to the values observed for the control medium. Besides, at the beginning of the fermentations, higher glycerol and ethanol production rates were observed, independently on glucose concentration in hydrolysate. These sub-products were also assimilated by yeast, mainly after $72 \mathrm{~h}$, when carbon sources (xylose, glucose, arabinose and acetic acid) were totally consumed.

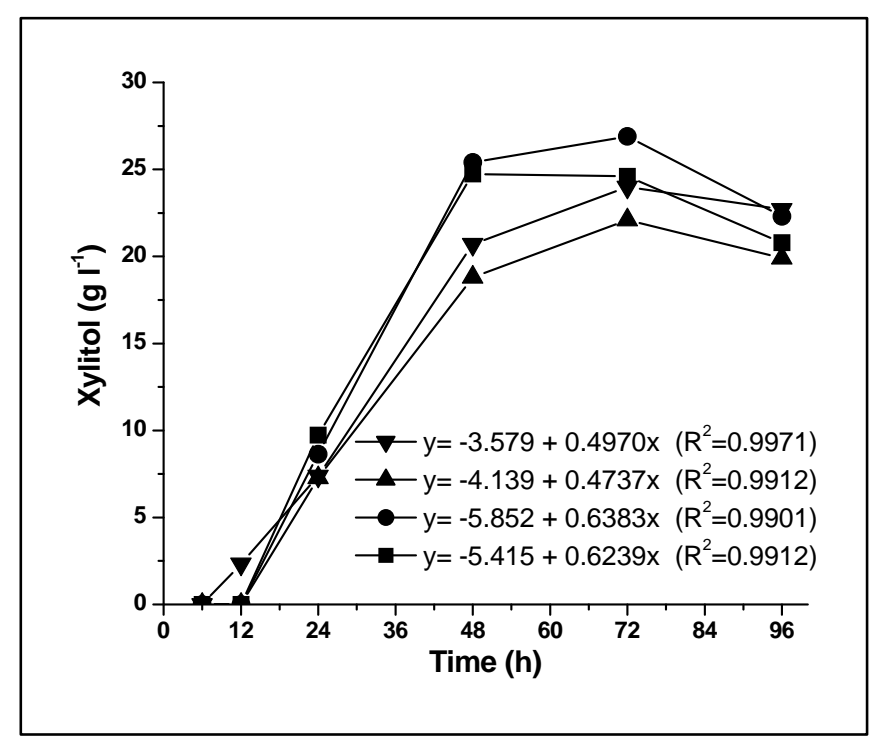

Figure 3 - Xylitol formation during fermentations of sugarcane bagasse hydrolysate by Candida guilliermondii, with different glucose:xylose ratios: 1:25 (down triangle), 1:12 (up triangle), 1:5 (circle) and 1:2.5 (square).

\section{DISCUSSION}

Evaluating the effect of the glucose:xylose ratio on xylose-to-xylitol bioconversion by $C$. guilliermondii in sugarcane bagasse hydrolysate it was observed that increasing this ratio resulted in increase of xylose consumption rate, except during the first $6 \mathrm{~h}$ of fermentation. The increase in glucose:xylose ratio resulted in a lag phase in xylose consumption at the beginning of fermentation, mainly employing the highest glucose concentration. This result indicated a possible catabolite repression caused by glucose on the enzymes responsible for xylose assimilation, such as xylose reductase.

The regulatory effects of D-glucose may be exerted on D-xylose transport or on parts of the Dxylose inducible pathway. In the yeasts D-glucose regulation may be in the form of either catabolite repression, inhibition of the synthesis of certain enzymes or catabolite inactivation, inhibition of the activity of some enzymes (Webb and Lee 1990). The effect of glucose on xylose-to-xylitol bioconversion was associated with the glucose:xylose ratio, occurring high inhibition in xylitol formation by $C$. guilliermondii with the increase of this ratio in synthetic medium (Felipe et al. 1993).

In this work, simultaneous utilization of sugars and acetic acid by $C$. guilliermondii was observed independent of glucose concentration in sugarcane bagasse hydrolysate (Fig. 2), and a higher consumption rate for glucose, xylose, acetic acid and arabinose. This behaviour could be explained by the fact that the enzymes required for glucose metabolism are constitutive enzymes or enzymes full time required by the cells and maintained in constant levels (Dawes and Sutherland 1992). 
Simultaneous use of xylose and glucose was observed by Tavares et al. (2000) during cultivation of $D$. hansenii in synthetic medium; however, a catabolic repression of xylose assimilation by glucose occurred when increasing amounts of glucose (glucose:xylose $=1: 10$ ) were added to the medium. In contrast, many works relate sequential sugar utilization, with preferential glucose assimilation in fermentation of sugar mixture (Preziosi-Belloy et al. 1997; Oh and Kim 1998; Walther et al. 2001).

Beneficial effects of glucose on xylose-to-xylitol bioconversion were also observed by PreziosiBelloy et al. (1997) during cultivation of Candida parapsilosis in synthetic medium with glucose:xylose ratio of 1:2.5. In this case, a reduction of fermentation time and an increase of $19 \%$ in xylitol yield $\left(0.50 \mathrm{~g} \mathrm{~g}^{-1}\right)$ in relation to the medium without glucose were observed. This improvement was also observed during the cultivation of $D$. hansenii in synthetic medium (Tavares et al. 2000). These authors observed an increase of $30 \%$ in xylitol yield $\left(\mathrm{Y}_{\mathrm{P} / \mathrm{S}}=0.56 \mathrm{~g} \mathrm{~g}^{-1}\right)$, employing a glucose:xylose ratio of $1: 10$ in relation to the medium without glucose. During cultivation of $C$. tropicalis in synthetic medium with glucose:xylose ratios ranging from 1:6 to 1:0.75, low ratios (1:6 and 1:3) did not have any appreciable effects on xylitol yield under microaerobic conditions (Walther et al. 2001).

A decrease in xylitol concentration after $72 \mathrm{~h}$ fermentation was observed, indicating that polyol could be assimilated by $C$. guilliermondii, besides, the decrease in values of xylitol yield and productivity (Tab. 2) could be directly associated with xylitol consumption by yeast. This reduction in xylitol concentration was also observed during the cultivation of $C$. guilliermondii in synthetic medium (Felipe et al. 1995) and in sugarcane bagasse hydrolysate (Felipe et al. 1996; Sene et al. 1998), and also during the cultivation of $C$. tropicalis in synthetic medium (Walther et al. 2001). Recently, experiments performed in our laboratories revealed that xylitol was utilized as a carbon source by $C$. guilliermondii for cell growth (Silva and Felipe 2006).

Formation of glycerol and ethanol by-products during this metabolism was also improved by the increase in glucose:xylose ratio. Higher production rate was observed at the beginning of the fermentations, while glucose was not depleted, indicating that these metabolites mainly came from glucose metabolism. The higher formation of these compounds with increasing the initial glucose concentration in fermentation medium was expected, since they were the result of the hexose metabolism, and had an important role in the regeneration of NAD, which was necessary to maintain the redox balance and to prevent the stalling of glycolysis (Walker 1998).

Thus, glycerol and ethanol formation by yeast might have been favourable to xylose-xylitol bioconversion because the NAD regeneration would have avoided the accumulation of NADH. This storing of NADH, cofactor required by xylitol dehydrogenase enzyme, could have increased the xylitol to xylulose conversion, to the detriment of its accumulation and subsequent excretion to the medium.

Ethanol formation, very fast at the beginning of all the runs, was also observed in fermentations of sugarcane bagasse hydrolysate by $C$. guilliermondii (Sene et al 2001). This was due to the poor contribution of xylose and arabinose reductive metabolism to its formation. The increase in ethanol formation by the increase in glucose concentration by $C$. tropicalis in synthetic medium containing xylose and glucose was also observed by Kastner et al. (2001) and Walther et al. (2001). Ethanol production was very rapid at the beginning of the cultivation and remained almost constant throughout the run. The decrease in ethanol and glycerol concentrations observed during all fermentations of sugarcane bagasse hydrolysate suggested their utilization as carbon and energy source by $C$. guilliermondii, mainly when sugars present in hemicellulosic hydrolysate were depleted in the medium, since the cell growth was not prejudiced. Otherwise, the glycerol and ethanol consumption was accompanied by an increase in cell growth (Fig. 3). According to Flores et al. (2000), glycerol and ethanol could be used as carbon and energy source by many yeasts. The xylose metabolism by $C$. guilliermondii cultivated in hemicellulosic sugarcane bagasse hydrolysate was improved by increasing glucose:xylose ratio in the medium, resulting in an improvement of xylitol formation by yeast.

\section{ACKNOWLEDGEMENTS}

This study was financially supported by (Fundação de Amparo à Pesquisa do Estado de São Paulo), CAPES (Coordenação de Aperfeiçoamento de Pessoal de Nível Superior) and CNPq (Conselho 
Nacional de Desenvolvimento Científico e Tecnológico). The authors are grateful to Lilian Cristina Marton Robin for revising this paper.

\section{RESUMO}

O efeito da glicose na bioconversão de xilose em xilitol por Candida guilliermondii foi avaliado em hidrolisado hemicelulósico de bagaço de cana com diferentes relações glicose:xilose $(1: 25,1: 12,1: 5$ and 1:2,5). Sob as condições experimentais, o aumento da relação glicose:xilose favoreceu a assimilação da xilose presente no hidrolisado, resultando em aumento da biomassa celular e aumento da formação de xilitol e dos sub-produtos glicerol e etanol. Os valores máximos do fator de conversão de xilose em xilitol $\left(0,59 \mathrm{~g} \mathrm{~g}^{-1}\right)$ e da produtividade volumétrica de xilitol $\left(0,53 \mathrm{~g} \mathrm{l}^{-1} \cdot \mathrm{h}^{-1}\right)$ foram obtidos com a relação glicose:xilose 1:5, resultando na maior eficiência de conversão $(64,3 \%)$.

\section{REFERENCES}

Aguiar, C. L., Oetterer, M. and Menezes, T. J. B. (1999), Caracterização e aplicações do xilitol na indústria alimentícia. Boletim SBCTA 33 (2), 184-193

Alves, L. A., Felipe, M. G. A., Almeida e Silva, J. B., Silva, S. S. and Prata, A. .M. R. (1998), Pretreatment of sugarcane bagasse hemicellulose hydrolysate for xylitol production by Candida guilliermondii. Applied Biochem. Biotechnol., 70-72, 89-98

Canettieri, E. V., Almeida e Silva, J. B. and Felipe, M. G. A. (2002), Obtenção biotecnológica de xilitol a partir de cavacos de eucalipto. Brazilian J. Pharmac. Sciences, 38 (3), 323-331

Canilha, L., Candido, E. J. and Almeida e Silva, J. B. (2003), Xylitol production from wheat straw hydrolysate using stirred tank reactor. Paper presented at XIV Simpósio Nacional de Fermentações, 5-8 August, Florianópolis

Chung, Y-S., Kim, M-D., Lee, W-J., Ryu, Y.W., Kim, J-H. and Seo, J-H. (2002), Stable expression of xylose reductase gene enhances xylitol production in recombinant Saccharomyces cerevisiae. Enz. Microbial Technol., 30, 809-816

Dawes, I. M. and Sutherland, I. W. (1992) Microbial Physiology. pp. 289. Oxford: Blackwell Science.

Felipe, M. G. A., Mancilha, I. M., Vitolo, M., Roberto, I. C., Silva, S. S. and Rosa, S. A. (1993), Preparation of xylitol by fermentation of a hydrolyzate of hemicellulose obtained from sugarcane bagasse. Arq Biol. Tecnol., 36 (1), 103-114
Felipe, M. G. A., Vieira, D. C., Vitolo, M., Silva, S. S., Roberto, I. C. and Mancilha, I. M. (1995), Effect of acetic acid on xylose fermentation to xylitol by Candida guilliermondii. J. Basic Microbiol., 35 (3), 171-177

Felipe, M.G.A., Vitolo, M. and Mancilha, I. M. (1996), Xylitol formation by Candida guilliermondii grown in a sugarcane bagasse hemicellulosic hydrolysate: effect of aeration and inoculum adaptation. Acta Biotechnol., 16 (1), 73-79

Felipe, M. G. A., Hauly, M. C. O., Canettieri, E. V., Candido, E. J. and Tamanini, C. (2003), Avaliação da casca de aveia para obtenção de hidrolisado hemicelulósico e produção de xilitol por processo fermentativo. Paper presented at XIV Simpósio Nacional de Fermentações, 5-8 August, Florianópolis

Flores, C-L., Rodríguez, C., Petit, T. and Gancedo, C. (2000), Carbohydrate and energy-yielding metabolism in non-conventional yeasts. FEMS Microbiol. Reviews, 24, 507-529

Hahn-Hägerdal, B., Jeppsson, H., Skoog, K. and Prior, B. A. (1994), Biochemistry and physiology of xylose fermentation by yeasts. Enz. Microbial Technol., 16, 933-943

Kastner, J. R., Eitman, M. A. and Sarah, A. L. (2001), Glucose repression of xylitol production in Candida tropicalis mixed-sugar fermentations. Biotecnol. Letters ,23, 1663-1667

Makinen, K. K. (2000), Can the pentitol-hexitol theory explain the clinical observations made with xylitol? Medical Hypotheses, 54 (4), 603-613

Makinen, K. K., Isotupa, K. P., Kivilompolo, T., Makinen, P. L., Toiveanen, J. and Soderling, E. (2001), Comparison of erytritol and xylitol saliva stimulants in the control of dental plaque and Mutans streptococci. Caries Research, 35 (2), 129-135

Matilla, P. T., Svanberg, M. J., Jämsa, T. and Knuuttila, M. L. E. (2002), Improved bone biomechenical properties in xylitol-fed aged rats. Metabolism, 51 (1), 92-96

Meinander, N. Q., Boels, I. and Hahn-Hängerdal, B. (1999), Fermentation of xylose/glucose mixtures by metabolically engineered Saccharomyces cerevisiae strains expressing XYL1 and XYL2 from Pichia stipitis with and without overexpression of TAL1. Biores. Technol., 68, 79-87

Melaja, J. and Hämäläinen, L Process for Making Xylitol. US n.4.008.285. 15 fev. 1977

Mussatto, S. I. and Roberto, I. C. (2003), Produção de xilitol a partir da palha de arroz: otimização do tratamento do hidrolisado com carvão ativo, através da metodologia de superfície de resposta. Paper presented at XIV Simpósio Nacional de Fermentações, 5-8 August, Florianópolis

Oh, D-K. and Kim, S-Y. (1998), Increase of xylitol yield by feeding xylose and glucose in Candida tropicalis. Applied Microbiol. Biotechnol., 50, 419425 
Pirt, S.J. (1975) Principles of Microbe and Cell Cultivation. pp. 274. Oxford: Blackwell Scientific Publications.

Preziosi-Belloy, L., Nolleau, V. and Navarro, J. M.; (1997), Fermentation of hemicellulosic sugars and sugar mixtures to xylitol by Candida parapsilosis. Enz. Microbial Technol., 21, 124-129

Rodrigues, R. C. L. B., Felipe, M. G. A., Roberto, I. C. and Vitolo, M. (2003a) Batch xylitol production by Candida guilliermondii FTI 20037 from sugarcane bagasse hemicellulosic hydrolysate at controlled $\mathrm{pH}$ values. Bioprocess Biosystems Eng., 26, 103-107

Rodrigues, R. C. L. B., Felipe, M. G. A., Almeida e Silva, J. B. and Vitolo, M. (2003b), Response surface methodology for xylitol production from sugarcane bagasse hemicellulosic hydrolysate using controlled vacuum evaporation process vairables. Process Biochem., 38, 1231-1237

Rosa, S. M. A., Felipe, M. G. A., Silva, S. S. and Vitolo, M. (1998), Xylose reductase production by Cândida guilliermondii. Applied Biochem. Biotechnol., 70-72, 127-135

Sene, L., Felipe, M. G. A., Vitolo, M., Silva, S. S. and Mancilha, I. M. (1998), Adaptation and reutilization of Candida guilliermondii cells for xylitol production in bagasse hydrolysate. J. Basic Microbio., 38 (1), 61-69

Sene, L., Converti, A., Zilli, M., Felipe, M. G.A. and Silva, S. S. (2001), Metabolic study of the adaptation of the yeast Candida guilliermondii to sugarcane bagasse hydrolysate. Applied Microbiol. Biotechnol., 57, 738-743

Sugai, J. K. and Delgenes, J-P. (1995), Catabolite repression of inductin fo aldose reductase activity and utilization of mixed hemicellulosic sugars in candida guilliermondii. Current Microbiol., 31, 239-244

Silva, S. S., Vitolo, M., Pessoa JR, A. and Felipe, M. G. A. (1996), Xylose reductase and xylitol dehydrogenase activities of D-xylose-xylitolfermenting Candida guilliermondii. J. Basic Microbiol., 36 (3), 187-191
Silva, D. D. V., Felipe, M. G. A. (2006), Effect of glucose:xylose ratio on xylose reductase and xylitol dehydrogenase activities from Candida guilliermondii in sugarcane bagasse hydrolysate. J.Chem Technol Biotechnol 81, 1294-1300

Silva, D. D. V., Felipe, M. G. A., Mancilha, I. M. and Paula, F. P. (2004), Biotechnological production of xylitol from lignocellulosic materials. Bioforum Europe 8 (3), 56-57

Tavares, J. M., Duarte, L. C., Amaral-Collaço, M. T. and Gírio, F. M. (2000), The influence of hexoses addition on the fermentation of D-xylose in Debaryomyces hansenii under continuous cultivation. Enz. Microbial Technol., 26, 743-747

Uhari, M., Tapiainen, T. and Kontiokari, T. (2000), Xylitol in preventing acute otitis media. Vaccine, 19 (S1), s144-s147

Walker, G. M (1998), Yeast physiology and biotechnology. pp. 350. West Sussex:John Wiley and Sons Ltd.

Walther, T., Hensirisak, P. and Agblevor, F. A. (2001), The influence of aeration and hemicellulosic sugars on xylitol production by Candida tropicalis. Biores. Technol., 76, 213-220

Webb, S. R. and Lee, H. (1990), Regulation of Dxylose utilization by hexoses in pentose-fermenting yeasts. Biotechnol. Advances, 8, 685-697

Zabner, J., Seiler, M.P., Launspach, J.L., Karp, P.H., Kearney, W.R., Look, D.C., Smith, J.J. and Welsh, M.J. (2000), The osmolyte xylitol reduces the salt concentration of airway surface liquid and may enhance bacterial killing. $P N A S / U S A, 97$ (21), 11614-11619

Received: March 28, 2005 ; Revised: January 23, 2006; Accepted: October 27, 2006. 


\section{PÁGINA}

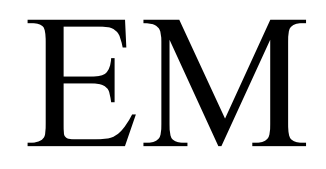

BRANCO 